14 Scott RS, Espiner EA, Donald RA. Intermittent Cushing's disease with spontaneous remission. Clin Endocrinol 1979;11:561-6.

15 Cushing $\mathrm{H}$. The basophil adenomas of the pituitary body and their clinical manifestations (pituitary basophilism). Bulletin of the Johns Hopkins Hospital 1932;50:137-95.

16 Anderson E, Haymaker W. Cushing's syndrome, 7 Ment Nerv Dis 1944:99-511-20.

17 Pasqualini RQ, Gurevich N. Spontaneous remission in a case of Cushing's syndrome. $7 \mathrm{Clin}$ Endocrinol Metab 1956:16:406-11.

18 Bassöe HH, Emberland R, Stöa KF. Fluctuating steroid excretion in Cushing's syndrome. Acta Endocrinol Copenh 1958;28:163-8.

19 Aber CP, Cheetham HD. Cyclical Cushing's syndrome. Br Med 7 1961;: 336-8.

20 Ovlisen B, Andersen HJ. Spontaneous remission in a case of Cushing's svndrome presumably due to adrenal tumor. F Clin Endocrinol 1966;26:294-8.

21 Ruder HJ, Loriaux DL, Lipsett MB. Severe osteopenia in young adults associated with Cushing's syndrome due to micronodular hyperplasia. F Clin Endocrinol Metab 1974;39:1138-47.

22 Blau N, Miller WE, Miller ER, Cervi-Skinner SJ. Spontaneous remission of Cushing's syndrome in a patient with an adrenal adenoma. $\mathcal{F}$ Clin Endocrinol Metab 1975;40:659-63.

23 Green JRB, Van't Hoff $W$. Cushing's syndrome with fluctuation due to adrenal adenoma. $\mathcal{F}$ Clin Endocrinol Metab 1975;41:235-40.

24 Bochner F, Burke CJ, Lloyd HM, Nurnberg BI. Intermittent Cushing's disease. Am J Med 1979;69:507-10.

25 James VHT, Landon J, Wynn V. Oral and intravenous suppression tests in the diagnosis of Cushing's syndrome. I Endocrinol 1965;33:515-24.

26 Brooks RV, Jeffcoate SL, London DR, Prunty FTG, Smith PM. Intermittent Cushing's syndrome with anomalous response to dexamethasone. $\mathcal{F}$ Endocrinol 1966;36:53-61.
27 French FS, Macfie JA, Baggett B, Williams TF, Van Wyk JJ. Cushing's syndrome with a paradoxical response to dexamethasone. Am f Med 1969;47:619-24.

28 Halberg F, Engeli $M$, Hamburger $C$. The 17-ketosteroid excretion of a healthy man on weekdays and weekends. Exp Med Surg 1965;23:61-69.

29 Costello RT. Subclinical adenoma of the pituitary gland. Am f Pathol 1936;12:205-15.

30 Burrow GN, Wortzman G, Rewcastle NB, Holgate RC, Kovacs K. Microadenomas of the pituitary and abnormal sellar tomograms in an unselected autopsy series. $N$ Engl $\mathrm{f} \mathrm{Med}$ 1981;304:156-8.

31 Spark RF, Dickstein G. Bromocriptine and endocrine disorders. Ann Intern Med 1979;90:949-56

32 Lamberts SWJ. Klijn JGM. De Quijada M et al The mechanism of the suppressive action of bromocriptine on adrenocorticotropin secretion in patients with Cushing's disease and Nelson's undrome. F Clin Endocrinol Metab 1980:51:307-11.

33 Kennedy AL, Sheridan B, Montgomery DAD. ACTH and cortisol response to bromocriptine, and results of long-tern therapy in Cushing's disease. Acta Endocrinol Copenh 1978;89:461-8. 34 Krieger DT, Amorosa L, Linick F. Cyproheptadine-induced remission of Cushing's disease. NEngl J Med 1975;293:893-6.

35 Grant DB, Atherden SM. Cushing's disease presenting with growth failure: clinical remission during cyproheptadine therapy. Arch Dis Child 1979;54:466-8

36 Hsu T, Gann DS, Tsan K, Russell RP. Cyproheptadine in the control of Cushing's disease. Fohns Hopkins Medical Journal 1981;149:77-83.

\title{
Long term effects of cyclophosphamide on testicular function
}

\author{
A R WATSON, C P RANCE, J BAIN
}

\begin{abstract}
Thirty men treated in childhood with cyclophosphamide for a mean of 280 days were assessed at a mean of 12.8 years after treatment for hormone concentrations and spermatogenesis. Four were azoospermic, nine oligospermic, and 17 normospermic. There was a significant inverse correlation of sperm density with cyclophosphamide dosage and duration of treatment. After a further mean follow up of $7 \cdot 2$ years three patients who were previously oligospermic and one who was azoospermic had normal sperm counts. All patients had normal sexual characteristics and libido. Serum androgen and prolactin concentrations did not differ significantly between patients and controls. Raised basal and stimulated follicle stimulating hormone concentrations were in keeping with impaired spermatogenesis. All patients had significantly raised luteinising hormone responses on stimulation with luteinising hormone releasing hormone.

The results suggest compensated Leydig cell failure, and patients with this condition require long term evaluation of testicular function. Potential recovery of spermatogenesis with time requires appropriate counselling and contraceptive advice.
\end{abstract}

\section{Introduction}

Early controlled clinical trials showed that cyclophosphamide effectively maintained remission of the childhood nephrotic

\footnotetext{
Division of Nephrology, The Hospital for Sick Children, Toronto, Ontario, Canada M5G 1X8

A R WATSON, MB, MRCP, consultant nephrologist

C P RANCE, MD, FRCP, consultant nephrologist

Division of Endocrinology and Metabolism, Mount Sinai Hospital, Toronto, Ontario, Canada

J BAIN, MD, FRCP, consultant endocrinologist
}

Correspondence to: Dr Watson, Department of Paediatrics, City Hospital, Nottingham NG5 1PB. syndrome in patients who were sensitive to steroids and had frequent relapses. ${ }^{1-3}$ Until 1972 the gonadal toxicity of this drug was not appreciated. ${ }^{4}$ Subsequent reports, however, have suggested a significant inverse correlation of sperm density with cyclophosphamide dosage..$^{6-8}$

In adult patients rendered azoospermic by cyclophosphamide recovery of spermatogenesis has been documented for up to four years after treatment, a finding that has obvious implications for fertility counselling and contraceptive advice. ${ }^{9}$ Little information is available on the long term outcome with respect to recovery of spermatogenesis in patients who were treated with large doses of cyclophosphamide during childhood. In addition, as most childhood patients have been studied either prepubertally or in early adulthood reports on their testicular hormone and gonadotrophin concentrations have been confusing. ${ }^{10-12}$

This study correlates gonadal effects with cyclophosphamide dosage in a large, single centre study and documents any recovery of spermatogenesis in patients who were tested and reported on previously. ${ }^{8}$ In addition, the responses of the sex hormones of such patients were determined.

\section{Patients and methods}

Men who were aged 17 or older in 1983 and had been treated with cyclophosphamide for childhood nephrotic syndrome at The Hospital for Sick Children, Toronto, between 1967 and 1976 were considered eligible for this study. Of 70 such patients, 28 were unavailable, two had died in motor vehicle accidents, seven refused to participate, and 33 were included in the study. Three patients were subsequently excluded from analysis owing to chronic renal failure (two patients) or a single testis (one patient).

In the 30 remaining patients histological examination before treatment with cyclophosphamide showed minimal lesions in 27 and focal segmental glomerulosclerosis in three. They had been treated with cyclophosphamide at a dose of $2-3 \mathrm{mg} / \mathrm{kg}$ body weight/day for a mean of 280 days (range 42-556). Thirteen patients had received treatment for a year or longer. Two had undergone two courses of treatment roughly two years apart, and the sum of the two courses was used to calculate the dose of cyclophosphamide.

When reviewed in 1983 all 30 patients were well and free of oedema. The three who had focal segmental glomerulosclerosis continued to have proteinuria with no clinical evidence of nephrosis or serious renal impairment. Two of the six patients with minimal lesions who relapsed after 
cyclophosphamide continued to do so but remained responsive to steroids. No evidence of malignancy was found in any of these patients.

The mean age of the 30 patients at evaluation was 22 years (range 17-29.5), the mean age at the time of treatment with cyclophosphamide was 9.4 years (range 2.9-17.3), and the mean time from the end of treatment with cyclophosphamide to the time of the study was $12 \cdot 8$ years (range $6 \cdot 7-15 \cdot 8$ ).

A control population of 18 men (mean age $28 \cdot 6$ years, range $18 \cdot 5-38 \cdot 5$ ) was drawn from donors to an artificial insemination programme and from healthy volunteers.

The study protocol was approved by the human experimentation committees of The Hospital for Sick Children and the University of Toronto. Thirteen patients had been tested previously and the results reported. ${ }^{8}$ All patients were examined clinically, and testicular length and breadth were measured when the patients were relaxed and recumbent. Testicular volume was determined by the method of Cantu et al ${ }^{13}$ in which the testis is regarded as an ellipsoid and volume equals $\pi / 6 \times$ length $\times$ width squared in cubic centimetres. Semen was obtained by masturbation in a private bathroom in the hospital after a period of abstinence of at least 48 hours. Analysis was performed within one hour for semen volume, sperm density, and percentage of motility and normal forms. Patients with sperm
TABLE II-Findings in patients whose sperm counts improved with time

\begin{tabular}{|c|c|c|c|c|c|c|}
\hline \multirow{2}{*}{ Case No } & \multirow{2}{*}{$\begin{array}{c}\text { Age when } \\
\text { cyclo- } \\
\text { phosphamide } \\
\text { was prescribed } \\
\text { (years) }\end{array}$} & \multirow[b]{2}{*}{$\begin{array}{l}\text { Total dosage } \\
(\mathrm{mg})\end{array}$} & \multicolumn{2}{|c|}{ Previous evaluation } & \multicolumn{2}{|c|}{ Current state } \\
\hline & & & $\begin{array}{c}\text { Age } \\
\text { (years) }\end{array}$ & $\begin{array}{l}\text { Sperm count } \\
\left(\times 10^{6} / \mathrm{ml}\right)^{\star}\end{array}$ & $\begin{array}{c}\text { Age } \\
\text { (years) }\end{array}$ & $\begin{array}{l}\text { Sperm count } \\
\left(\times 10^{6} / \mathrm{ml}\right)^{\star}\end{array}$ \\
\hline 1 & $11 \cdot 7$ & 9000 & $15 \cdot 5$ & 12 & $22 \cdot 9$ & 70 \\
\hline 2 & $16 \cdot 4$ & 6300 & 20.8 & 0.4 & $26 \cdot 3$ & 80 \\
\hline 3 & $11 \cdot 3$ & 36200 & 18.7 & 12.5 & $25 \cdot 5$ & 25 \\
\hline 4 & $17 \cdot 3$ & 46550 & $22 \cdot 9$ & 0 & 31.9 & 22 \\
\hline
\end{tabular}

^Minimum of two samples checked

occasional). Five patients were married and one, who was oligospermic (sperm density $12 \times 10^{6} / \mathrm{ml}$ ), fathered a child.

Mean (SE) serum concentrations of testosterone $(24 \cdot 3(2 \cdot 4) \mathrm{nmol} / \mathrm{l}(0 \cdot 7$ $(0.07) \mu \mathrm{g} / \mathrm{l}) v 27.1(2.9) \mathrm{nmol} / \mathrm{l}(0.78(0.08) \mu \mathrm{g} / \mathrm{l}))$, dehydroepiandrosterone sulphate $(10.7(1.0) \mu \mathrm{mol} / \mathrm{l}(3932(367 \cdot 4) \mu \mathrm{g} / \mathrm{l}) v 12 \cdot 2(0.9) \mu \mathrm{mol} / \mathrm{l}(4482$ $(330 \cdot 6) \mu \mathrm{g} / \mathrm{l}))$, and prolactin $(11 \cdot 7(1 \cdot 1) v 14 \cdot 2(1 \cdot 1) \mu \mathrm{g} / \mathrm{l})$ were not

TABLE I-Pubertal state in 30 patients at time of treatment with cyclophosphamide, comparing mean (SE) current testicular volumes and semen analyses with those in normal controls

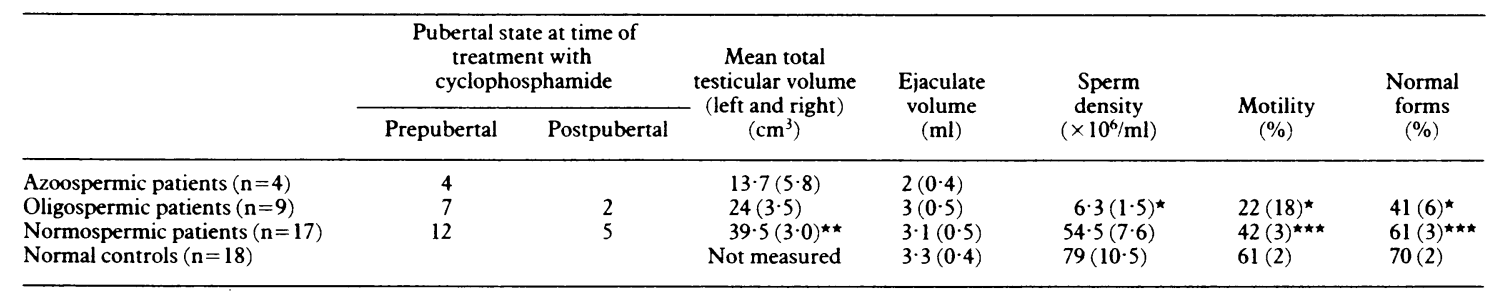

${ }^{\star} \mathrm{p}<0.005 v$ control group; ${ }^{\star \star} \mathrm{p}<0.005 v$ oligospermic and azoospermic groups; ${ }^{\star \star \star} \mathrm{p}<0.05 v$ control group.

counts of less than $20 \times 10^{6} / \mathrm{ml}$ had a repeat analysis. Semen analysis was carried out in the same manner for the control group, who were not examined clinically.

Blood samples were taken in the resting state to measure serum creatinine, albumin, testosterone, prolactin, and dehydroepiandrosterone sulphate concentrations. Two basal blood samples were also taken to measure luteinising hormone and follicle stimulating hormone concentrations. Synthetic luteinising hormone releasing hormone (Fractrel (R) Ayerst, Canada) $100 \mu \mathrm{g}$ was administered intravenously and further blood samples were obtained after 20,45 , and 60 minutes to measure luteinising hormone and follicle stimulating hormone concentrations by radioimmunoassay.

Each patient was asked about his sexual performance and libido and arbitrarily classified using the categories of Chapman et al ${ }^{14}$ as "strong" (sexual intercourse or masturbation four times or more a week), "moderate" (two to four times a week), "occasional" (once a month to once a week), or "none" (no sexual activity).

Statistical analysis among groups was performed with non-paired $t$ tests.

\section{Results}

Of the 30 patients, four were azoospermic, nine oligospermic (sperm count $\leqslant 20 \times 10^{6} / \mathrm{ml}$ ), and 17 normospermic (sperm count $\geqslant 20 \times 10^{6} / \mathrm{ml}$.) Table I shows the pubertal state at the time of treatment with cyclophosphamide. Although there was no significant correlation of total testicular volume with sperm density, the three groups of patients differed significantly in mean total testicular volume. The variables of sperm of lower percentage motility and a lower percentage of normal forms paralleled a decreasing sperm count, with significant differences noted between patients who were oligospermic or normospermic and the controls. A significant inverse correlation was evident between sperm density and cyclophosphamide dosage in terms of duration of treatment and total dosage (fig 1).

Thirteen patients had undergone a semen analysis $5 \cdot 5-9$ years previously, and the results have been reported. ${ }^{8}$ Nine of them remained in the same categories in this study (four normospermic, three azoospermic, and two oligospermic), but four who had had a low or, in one case, no sperm count before were found to be normospermic after an average additional follow up of $7 \cdot 2$ years (table II).

All patients had normal secondary sex characteristics with no noticeable decrease in libido and sexual function (two strong, eight moderate, and 20 significantly different between patients receiving treatment and those in the control group.

Both basal and peak follicle stimulating hormone concentrations were significantly raised in the oligospermic and azoospermic patients compared with those in the control group, as was the peak follicle stimulating hormone concentration in the normospermic group (fig 2). Basal luteinising hormone concentrations in the azoospermic and oligospermic patients were significantly raised compared with those in the controls, and peak concentrations were significantly different between all patients and controls (fig 3).

\section{Discussion}

This study is the longest follow up of men who, with few exceptions, were treated with doses of cyclophosphamide above those currently recommended for childhood nephrosis treated for 612 weeks at a dose of $2-3 \mathrm{mg} / \mathrm{kg}$ body weight. ${ }^{15}$ The fact, however, that $25(93 \%)$ of the patients with minimal lesions were still in remission two years after treatment and at the time of the present study shows the effectiveness of the regimen. Restriction of treatment with cyclophosphamide to $3 \mathrm{mg} / \mathrm{kg}$ body weight/day for eight weeks seems to have only a mild effect on spermatogenesis, but the remission rate at two years is roughly $50 \% .1516$

Our single centre study emphasises the significant inverse correlation of sperm density with cyclophosphamide dosage in terms of duration of treatment and total dosage. These variables seem to be more important than the pubertal state of the subject at the time of treatment, although this remains debatable. ${ }^{17}{ }^{18}$ None of the patients who were treated for less than 112 days (four months) and received less than $10 \mathrm{~g}$ (or less than $300 \mathrm{mg} / \mathrm{kg}$ body weight) of the drug had a sperm count of less than $20 \times 10^{\%} / \mathrm{ml}$, which is the currently accepted normal level for healthy men. ${ }^{19}$ Indeed, none of our control group had a sperm count of less than $22 \mathrm{million} / \mathrm{ml}$. One oligospermic patient in our series, however, fathered a child, and this has also been reported by other workers. ${ }^{14}$

Although Buchanan $e t a l^{\prime}$ reported recovery of spermatogenesis in half of adults up to 49 months after treatment with cyclophosphamide, there is a paucity of information on the long term outcome. 
This report documents considerable improvement in sperm counts in four of nine previously tested men after a further mean follow up of $7 \cdot 2$ years. Our findings have obvious implications for contraceptive advice and are also encouraging for those who have been treated with cyclophosphamide for conditions other than nephrosis. ${ }^{20}$
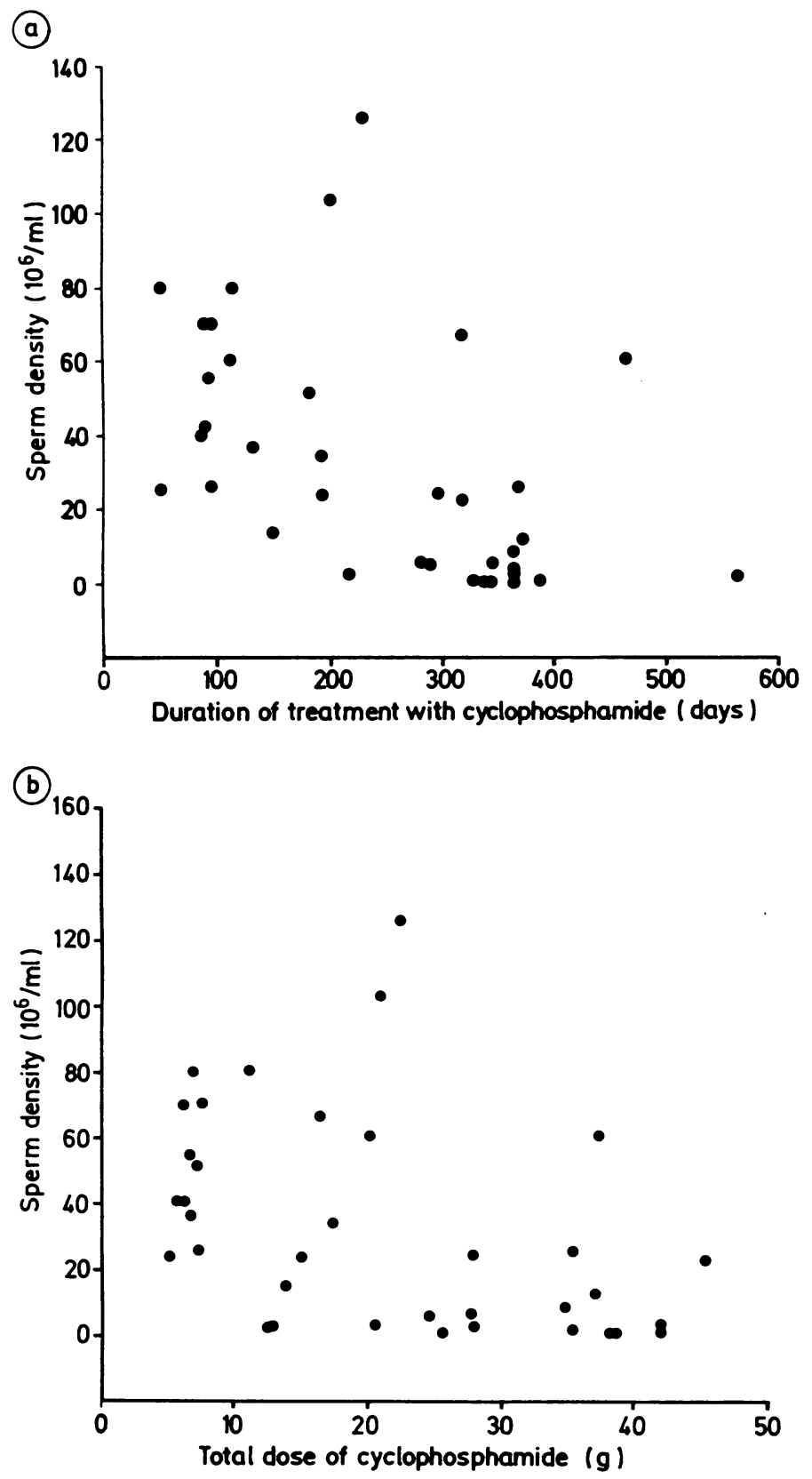

FIG la-Sperm density in 36 patients with childhood nephrotic syndrome treated with cyclophosphamide correlated with duration of treatment $(r=0.49, p<0.01)$, including three previously reported ${ }^{8}$ and three unpublished observations in patients not retested for current series.

FIG $1 \mathrm{~b}$-Sperm density in 36 patients with childhood nephrotic syndrome treated with cyclophosphamide correlated with total dosage $(r=0.43, p<0.01)$, including three previously reported ${ }^{8}$ and three unpublished observations in patients not retested for current series.

Although there appeared to be no overall significant correlation between total testicular volume and sperm density at the time of the study, azoospermic and oligospermic patients had lower mean testicular volumes than normospermic patients and adults in the published reports. ${ }^{21}$ No testicular biopsies were performed in our series but germinal cell aplasia has been well documented in patients treated with cyclophosphamide with apparently intact Leydig

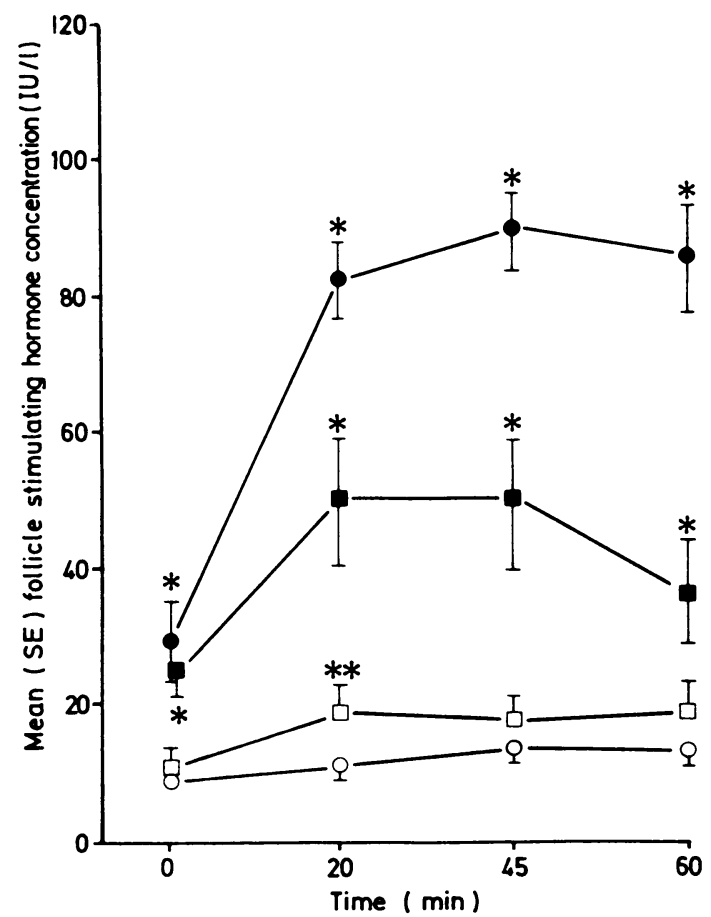

FIG 2-Response of follicle stimulating hormone concentration to intravenous injection of $100 \mu \mathrm{g}$ luteinising hormone releasing hormone. Four azoospermic patients $(\bullet)$, nine oligospermic $(\square), 17$ normospermic $(\square)$, and 18 controls $(O)$. ${ }^{\star} \mathrm{p}<0.01 ;{ }^{\star} \mathrm{p}<0.05$

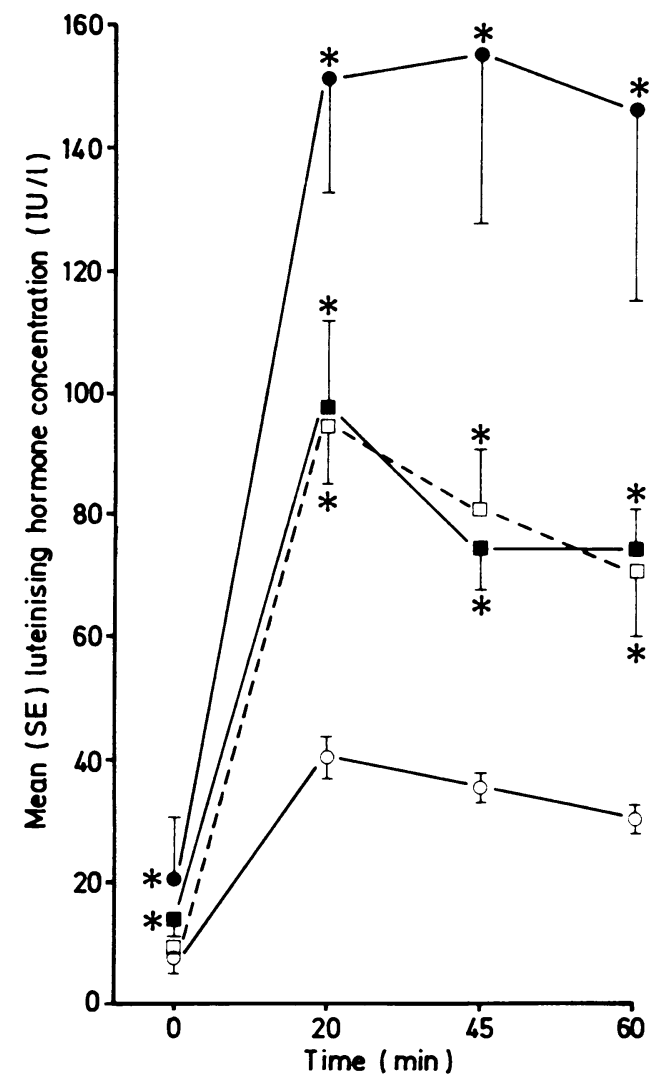

FIG 3-Response of luteinising hormone concentration to intravenous injection of $100 \mu \mathrm{g}$ luteinising hormone releasing hormone. Four azoospermic patients $(\bullet)$ nine oligospermic $(\square), 17$ normospermic $(\square)$, and 18 controls $(0) .{ }^{\star} p<0 \cdot 01$.

cells. ${ }^{6} 1122$ Most testicular biopsies, however, have been done in young patients, and the obliteration of Leydig cells may be a slow, progressive phenomenon. Raised follicle stimulating hormone 
concentrations both in the basal state and after stimulation with luteinising hormone releasing hormone suggest seminiferous tubular insufficiency. ${ }^{2324}$ Thus the significantly raised concentrations in oligospermic and azoospermic patients are in keeping with germinal cell damage. Although the normospermic patients were classified as "normal" on the basis of their sperm counts, the significantly raised peak follicle stimulating hormone concentrations in this group also suggest that they have not escaped similar damage.

One of the most important findings of our study was the greatly exaggerated peak response of luteinising hormone on testing with luteinising hormone releasing hormone in all patients, irrespective of their sperm count. As luteinising hormone binds only to Leydig cells an exaggerated response on testing with luteinising hormone releasing hormone of normal testosterone concentrations indicates compensated Leydig cell failure. ${ }^{25}$ Other studies have noted raised basal luteinising hormone concentrations in some patients treated with high doses of cyclophosphamide, but evaluation has often taken place peripubertally with conflicting results. ${ }^{6726}$ Kirkland et al reported an exaggerated response of luteinising hormone to luteinising hormone releasing hormone in patients treated prepubertally or pubertally; but they did not record semen analyses. ${ }^{12}$ Further evaluation of the incipient Leydig cell failure suggested by these results will require the assessment of responses of testicular hormones to stimulation with human chorionic gonadotropic hormone as our patients currently have normal secondary sex characteristics and libido with normal testosterone concentrations.

This study confirms the significant inverse correlation of cyclophosphamide dosage wth its effect on spermatogenesis and documents clearly, for the first time, the long term effects on the Leydig cell component of the testis. The recovery of sperm counts in some subjects after a prolonged interval after treatment is encouraging. All patients treated with high doses of cyclophosphamide should have regular estimations of testicular hormone concentrations as Leydig cell failure may develop with time even in normospermic subjects.

We thank Carmela Schonberg for performing the tests for luteinising hormone releasing hormone, Dina Eftimescu for help with the semen analyses, and the Medical Publications Department, The Hospital for Sick Children, for help in preparing the manuscript.

\section{References}

1 Barratt TM, Soothill JF. Controlled trial of cyclophosphamide in steroid-sensitive relapsing nephrotic syndrome of childhood. Lancet 1970;ii:479-82.

2 Chiu J, McLaine PN, Drummond KN. A controlled prospective study of cyclophosphamide in relapsing corticosteroid-responsive, minimal-lesion nephrotic syndrome in childhood. $\mathcal{F}$ Pediatr 1973;82:607-13.

3 Spitzer A, Gordillo PG, Houston IB, Travis LB. Prospective, controlled trial of cyclophosphamide therapy in children with the nephrotic syndrome. Report of the International Study of Kidney Disease in Children. Lancet 1974;ii:423-7.

4 Fairley KF, Barrie JU, Johnson W. Sterility and testicular atrophy related to cyclophosphamide therapy. Lancet 1972;i:568-9.

5 Kumar R, Biggart JD, McEvoy J, McGeown MG. Cyclophosphamide and reproductive function Lancet 1972;i:1212-4

6 Etteldorf JN, West CD, Pitcock JA, Williams DL. Gonadal function, testicular histology, and meiosis following cyclophosphamide therapy in patients with nephrotic syndrome. $\mathcal{J}$ Pediat 1976;88:206-12.

7 Lentz RD, Bergstein J, Steffes MW, et al. Postpubertal evaluation of gonadal function following cyclophosphamide therapy before and during puberty. $\mathcal{I}$ Pediatr 1977;91:385-94.

$8 \mathrm{Hsu}$ AC, Folami AO, Bain J, Rance CP. Gonadal function in males treated with cyclophosphamide for nephrotic syndrome. Fertil Steril 1979;31:173-7.

9 Buchanan JD, Fairley KF, Barrie JU. Return of spermatogenesis after stopping cyclophosphamide therapy. Lancet 1975; ii:156-7.

10 Penso J, Lippe B, Ehrlich R, Smith FG. Testicular function in prepubertal and pubertal male patients treated with cyclophosphamide for nephrotic syndrome. 7 Pediatr 1974;84:831-6.

11 Pennisi AJ, Grushkin CM, Lieberman E. Gonadal function in children with nephrosis treated with cyclophosphamide. Am $\mathcal{F}$ Dis Child 1975;129:315-8.

12 Kirkland RT, Bongiovanni AM, Cornfeld D, McCormick JB, Parks JS, Tenore A. Gonadotropin responses to luteinizing releasing factor in boys treated with cyclophosphamide for nephrotic
a syndrome. F Pediatr 1976;89:941-4.

13 Cantu J-M, Scaglia HE, Medina $M$, et al. Inherited congenital normofunctional testicular hyperplasia and mental deficiency. Hum Genet 1976;33:23-33.

14 Chapman RM, Sutcliffe SB, Rees LH, Edwards CRW, Malpas JS. Cyclical combination chemotherapy and gonadal function. Retrospective study in males. Lancet 1979;i:265-9.

15 Rance CP, Arbus GS, Balfe JW. Management of the nephrotic syndrome in children. Pediatr Clin North Am 1976;23:735-50.

16 Trompeter RS, Evans PR, Barratt TM. Gonadal function in boys with steroid-responsive nephrotic syndrome treated with cyclophosphamide for short periods. Lancet 1981;i:1177-9.

17 Parra A, Santos D, Cervantes C, Sojo I, Carranco A, Cortes-Gallegos V. Plasma gonadotropins and gonadal steroids in children treated with cyclophosphamide. 7 Pediatr 1978;92:117-24.

18 Rapola J, Koskimies O, Huttunen NP, et al. Cyclophosphamide and the pubertal testis. Lancet 1973;i:98-9.

19 Chong AP, Walters CA, Weinrieb SA. The neglected laboratory test. The semen analysis. $f$ Androl 1983;4:280-2.

20 Steinberg AD, Plotz PH, Wolff SM, Wong VG, Agus SG, Decker JL. Cytotoxic drugs in treatment of nonmalignant disease. Ann Intern Med 1972;76:619-42.

21 Farkas LG. Basic morphological data of external genitalia in 177 healthy central European men.

Am F Phys Anthropol 1971;34:325-8.
22 Arneil GC. Cyclophosphamide and the prepubertal testis. Lancet 1972;ii: 1259-60

23 Bain J, Moskowitz JP, Clapp JJ. LH and FSH response to gonadotropin releasing (GnRH) in normospermic, oligospermic and azoospermic men. Arch Androl 1978;1:147-52.

24 Rosen SW, Weintraub BD. Monotropic increase of serum FSH correlated with low sperm coun in young men with idiopathic oligospermia and aspermia. $\mathcal{J}$ Clin Endocrinol Metab 1971;32 $410-6$

25 Bain J. Male hypogonadism. Compr Ther 1983;9:17-24

26 DeGroot GW, Fairman C, Winter JSD. Cyclophosphamide and the prepubertal gonad: a negative report. 7 Pediatr 1974;84:123-5.

(Accepted 9 September 1985)

\section{YEARS AGO}

A certain amount of pleasure of its kind may doubtless, as stated by some authors, be derived from smoking opium. If it were not so, we should know nothing of the later and worse consequences of this practice. Such enjoyment as there is, it is true, is short-lived, and the after-effects produced by this drug, as most of those who have had occasion to use it are but too ready to admit, are sufficiently unpleasant, to say no more of them, to cure the craving of any but an eager student in experimental narcotism. It may be said that such difficulties are not insuperable. No, but they must be obviated by some system of counter-drugging, or by training the constitution by habit to bear a certain amount of the opium. But what amount? and how to bear it? These are questions which cannot be concisely answered. Quantity, in this case, comes readily to mean the measure of a constantly increasing appetite, and endurance is merely another name for an unhealthy slavery, difficulty to escape from, and difficult to live under, which may well be said to begin in delusion, and to end, commonly, in disastrous arrest of every useful function. Something may be said for moderation in the use of alcoholic liquors or tobacco. In regard to the habitual, or even occasional, employment of opiates outside of medical practice, there is no such term as moderation. Disease is their only excuse. Their value, therefore, is purely therapeutic, and the preferable form for their administration in most cases of illness, and merely with a view to their efficiency, is not that of inhalation. We have had occasion to write on this subject before, and have drawn attention to dangers other than moral or mental, or such as only generally affect the physical state. The fact that persons who often know nothing, or next to nothing, about their own health, and yet are the very unfittest subjects for such a drug as opium, may freely treat themselves with it for any casual pain or worry, appears to us a yet graver source of evil. To restrict the right of sale of this poison to chemists or dispensing practitioners, and to limit the privilege allowed to them, would encroach on no private right, and would give security where now there is none. We have been led to make these observations at the present time by seeing a card of advertisement, apparently for public distribution, which intimates that an establishment, where opium-smoking is taught, will shortly be opened in the West End of London. We sincerely deprecate any such arrangement, and trust that the introduction of such injurious novelties may do something to direct legal action in the way which we desire. A suggestion is made that medical men should avail themselves of the opium-pipe as a therapeutic agent. We feel sure that we represent the bulk of medical opinion in repudiating this suggestion. (British Medical Fournal 1885;ii:751.)

The itinerant fishmongers of Paris, in order to supply their customers with well cleaned fish, wash quantities of soles, whitings, plaice, etc., in the gutters, which are plentifully supplied with water. People who have the advantage of residing in the immediate vicinity of a good flowing gutter can frequently observe these sanitary precautions, and are thus forearmed and forewarned. Others, in this respect less fortunately placed, constantly purchase, in confiding innocence, fish cleaned in gutter-water flowing through Paris streets, and devour the same, prepared with that skill for which the French cook is famed, a skill which may conceal bad flavours, but cannot protect the consumer against the evil results of devouring contaminated food. (British Medical Fournal 1885;ii:1124.) 